\title{
АКТУАЛЬНІ ПРОБЛЕМИ ПСИХОЛОГІЧНОЇ ПРОТИДІЇ НЕГАТИВНИМ ІНФОРМАЦІЙНИМ ВПЛИВАМ НА ОСОБИСТІСТЬ ТА ШЛЯХИ ЇХ ПОДОЛАННЯ
}

\author{
Наукова доповідь на методологічному семінарі НАПН України \\ «Актуальні проблеми психологічної протидії негативним інформаційним \\ впливам на особистість в умовах сучасних викликів» 8 квітня 2021 p.
} https://doi.org/10.37472/2707-305X-2021-3-1-13-1

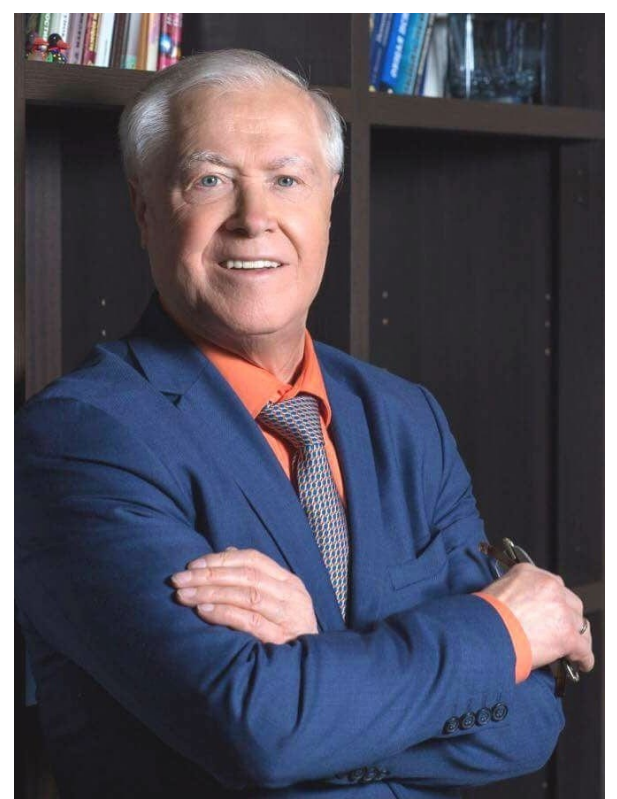

\section{МАКСИМЕНКО}

\section{Сергій Дмитрович}

доктор психологічних наук, профессор, дійсний член (академік) НАПН України, академік-секретар Відділення психології, вікової фізіології та десректології Національної академії педагогічних наук України; директор Iнституту психології імені Г.С. Костюка Національної академії педагогічних наук України, м. Київ, Україна

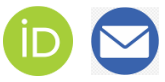

Анотація. Сутність соціальної ситуації у сучасному світі полягає в тому, що зросло значення психологічного фактору особистісного існування у формуванні та функціонуванні процесу, який викликаний пандемією. Ми не беремося аналізувати його складові, але ми можемо констатувати деякі речі, що з психологічного погляду захоплюють усі верстви населення $і$ впливають на ключові державні, політичні й економічні позищії. Це певна манія переслідування і дотримання правил захисту, що стало манічним станом у суспільстві. Манія переслідування стає домінуючою одиницею, до якої долучається алогічність мислення, що проявляється у неадекватному ставленні до світу й до себе, до рідних і близьких... I це є специфічною формою роздвоєння свідомості, коли з'являються незрозумілі та парадоксальні агресивно-депресивні синдроми. 3 одного боку, ие агресія, а з іншого - боязнь усього навколишнього.

Ключові слова: протидія негативним інформачійним впливам; особистість; неврози; COVID-19; рефлекс.

Актуальність проблеми психологічної убезпеченості людей, яким випало жити в наш непростий час, зумовлюється непередбачуваними наслідками однобічного, часто позбавленого гуманістичних вимірів науково-технічного прогресу, інформаційною перенасиченістю середовища людського існування, численними природними, техногенними та соціальними катастрофами, суспільними конфліктами і війнами, що дедалі більше набувають гібридного характеру.

Сучасне суспільство і кожна особистість переживає неоднозначні, різні за своєю формою, змістом і перебігом зміни (соціальні, політичні, економічні, гуманітарні та соціальноконфліктні), пов'язані із протистоянням негативним впливам, які чинить Російська Федерація на суспільство, народ і державу. Як влучно сказав В. Франкл: "Кожному періоду характерні свої неврози», і тому в цей період, свідомо чи несвідомо, природа спонукає людей до виживання в умовах пандемії. Таке враження, що це надприродний, але соціально-детермінований біологічний експеримент, який зачіпає не тільки фізичне здоров'я, зокрема метаболізм людини, а й геном. Геном $є$ дуже чутливим до всіх змін і привласнюється особистістю. Колективна свідо- 
мість призводить до того, що особистість нагадує крилату ракету й імітує усі спади, злети та падіння у суспільстві. Відбувається цілеспрямоване роз'єднання культурного ядра нації, етнічних груп, а уособлення цих груп призводить до нецілісності суспільства.

Цілісність суспільства полягає в об'єднанні нації, адже роз'єднане суспільство $€$ легкою здобиччю для ворога. Це зачіпає душу людини, проникає як стріли ворога і підважує світоглядні цілі, притаманні особистості. Тому потрібно, щоб методологія зберегла примат, як ми визначаємо за П.В.Копніним: «застосування принципів світогляду у пізнанні» до теорії, до практики та творчості зокрема. При такому дедилігізованому розумінні методології можна об'єднатися навколо ідеї, що мій світогляд - це як «гаманець у кишені». Я його привласнюю 3 дитинства, 3 дитячого садочка. Він стає моєю світоглядною одиницею. $Є$ факт, а $є$ філософія факту, як я стверджую. За простою реакцією реактолог буде бачити реакцію, рефлексолог - рефлекс, з позиції теорії діяльності - фрагмент діяльності, з погляду установки - установку, а факт - один. Сьогодні це і породило багато різних течій, теоретико-методологічних напрямів, які відкривають «хвіртку у Європу» своїми визначеннями та певними надуманими принципами і викривленою методологією.

Мета методологічного семінару в тому, щоб здійснити методологічну експертизу проблем розвитку психології, спираючись на практику та теорію. Тому коли ми говоримо, що нас спонукає обставина, що сучасна психологія підійшла до тієї риски, то, висловлюючись словами Л.С. Виготського «Дальнейшее продвижение по прямой линии, простое продолжение все той же работы, постепенное накопление материала оказывается бесплодным или даже невозможным». Ці питання спонукають здійснити рефлексію, щоб привести у відповідність наші дослідження і ті принципи та технології, що використовуються. Ось у чому суть сьогоднішнього методологічного семінару. Тим більше війна йде вже сьомий рік...

Пандемія триває уже другий рік. Коли люди відпочивають на ліжнику, в цьому моменті простежується роздрібненість, феодальний куточок, який треба затулити не просто ширмою. Його треба ліквідувати, вибудувавши стратегію захисту власної будівлі. Вираз «Моя хата скраю я нічого не знаю» є неправильним. Правильний вислів є таким: «Моя хата скраю - я перший ворогів зустрічаю». Обійстя для українця - це його родинне гніздо, його воля, правда, совість і ті застереження, які він посилає іншим невдячним, недоброзичливим людям. Тому наша культура відрізняється від багатьох культур тим, що ми маємо веселий норов. Наша нація співуча, музична, чуттєва, працьовита.

Хотілося 6 повернутися до ситуацій, які тривожать мене найбільше. Ситуації, що пов'язані із військовими діями на сході, та ситуації із панде-

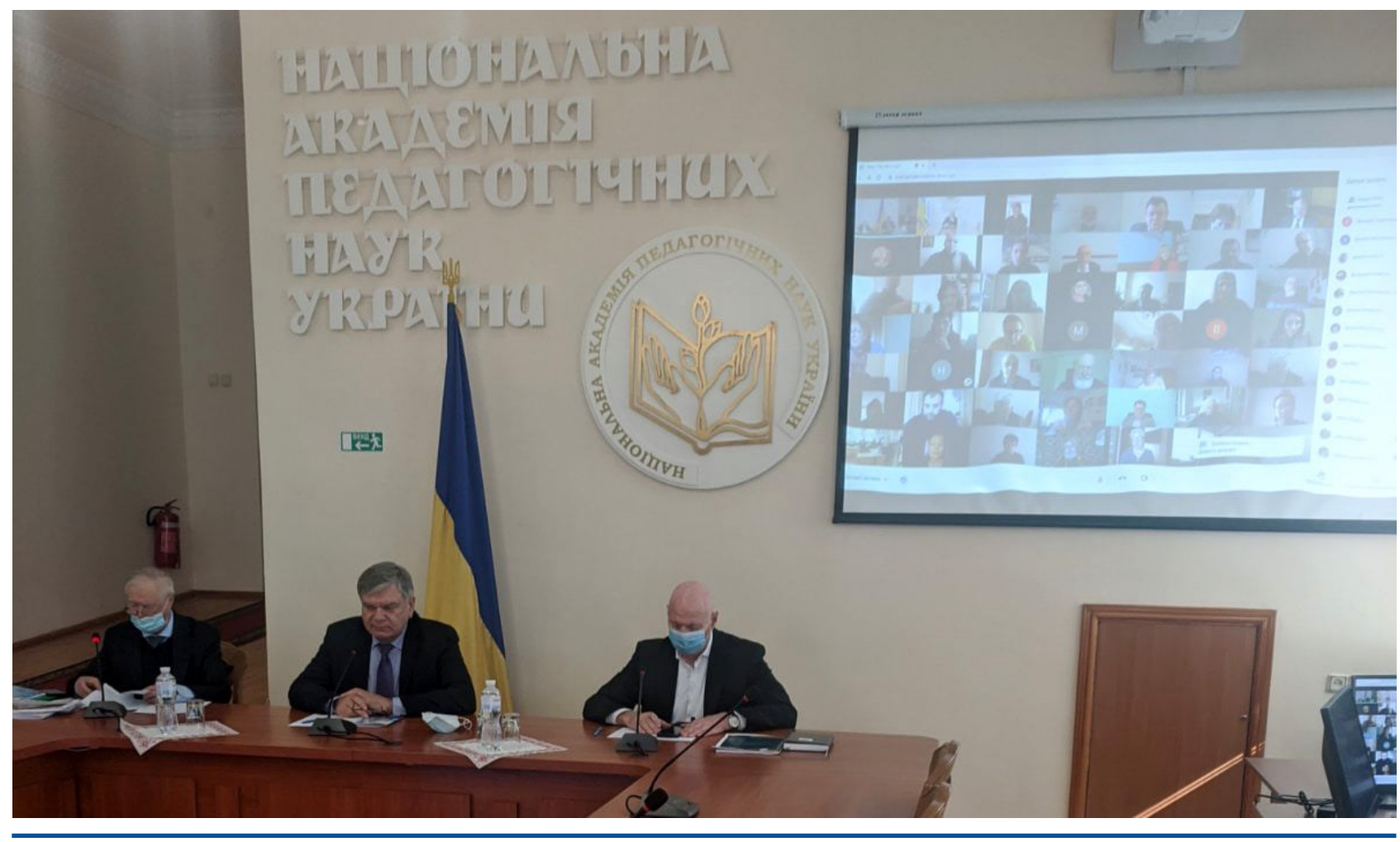


мією. Перш за все можна виділити три блоки психологічного переживання подій особистістю.

Освіта не повинна втрачати свій статус, оскільки в разі спроб маніпулювання - це єдине джерело, яке конституює три основні компетенції, що мають бути сформовані.

Як же відбуваються маніпуляції та впливи через коронавірус? Багато хто переживає це як специфічну форму 1. Обсесивного неврозу (манії), який полягає у тому, що людина весь час перебуває під пресом цього переживання. На ці переживання впливає значна частина негативної інформації зі 3МІ. Це перший блок і та сфера впливу на особистість людини, яку ми маємо захищати, для чого формується методологія практики та терапії.

Наступним блоком є 2. Алогічність мислення, коли в людини з'являються різні негативні стани (агресивний і депресивний). 3 одного боку, це агресія, а з іншого - страх усього навколишнього. Це психосоматична узалежненість від обставин буття, психогенний, психобіологічний тероризм у явному психологічному вигляді. Він зачіпає психологічний код через постулати недолугої ковідної пандемії, яка «накручує» такі речі, що здаються не зовсім логічними.

3. Роздвоєння свідомості призводить до неврозів і психопатій, які зачіпають морфологічні структури, макрологічні структури і геном. Відбувається певна редукція психічного стану роздвоєння свідомості на тілесну організацію особистості, що провокує емоційне отуплення.

4. Емоційне отуплення означає відсутність емоційних переживань, байдужість до ближнього тощо. Тому ці чотири складові $\epsilon$ і альфою, і омегою того, як повинна будуватися профілактика, протистояння і корекція власної поведінки особистості у суспільстві. На цих підвалинах і будується наша концепція протистояння. Ми переходимо до викладу матеріалу - того, що саме зроблено нами.

У наукових установах Відділення психології, вікової фізіології та дефектології Національної академії педагогічних наук України вказаним проблемам приділяється значна увага з огляду на те, що лише зріла особистість із високим рівнем інтелектуального розвитку здатна протистояти негативним інформаційним впливам, формуючи власний погляд на оточуючий світ.

Так, в Інституті психології імені Г.С. Костюка НАПН України всебічно досліджуються проблеми становлення суб'єктості особистості, оскільки важливим чинником інформаційної безпеки $\epsilon$ власна відповідальність зрілої людини перед собою за спожиту інформацію, їі аналіз і вплив. Суб'єктність особистості визначає її самостійність і самодостатність, готовність бачити проблеми, приймати складні рішення, толерантність до невизначеності, глибину прогнозування та передбачення. Психологічний зміст поняття «суб'єктність» включає англомовне поняття «асертивність», яке звичайно тлумачать як готовність до протидії маніпулюванню та іншим негативним впливам. Інтелект і суб'єктність дорослої людини забезпечують творчий, антиманіпулятивний і антикризовий потенціал особистості і, вочевидь, вимагають постійного розвитку і психологічної підтримки.

Слід також указати на дослідження, які проводяться в Інституті психології імені Г.С. Костюка НАПН України, щодо проблем розвитку життєстійкості та психологічного благополуччя людей різних вікових і професійних груп як вагомих чинників управління середовищем (здатність впливати на те, що відбувається), особистісного зростання (необхідність постійного самовдосконалення), позитивних взаємин із оточуючими (спрямованість на формування позитивних взаємин), особистісної автономії (відносна самостійність у функціонуванні та прийнятті рішень). Досліджено особливості функціонування творчого мислення студентів і старшокласників в ускладнених інформаційних умовах, молодших школярів - у процесі розв'язування нових задач, старших дошкільників - в умовах нових інформаційних ситуацій, а також прояви мислення дошкільників у ситуаціях інформаційної невизначеності, когнітивного реагування користувачів Інтернету на нові інформаційні повідомлення.

Серйозно досліджуються проблеми вербальної комунікації, яка є провідним чинником будьякої людської діяльності. Саме вербальний канал передачі інформації дає змогу не лише найбільш ефективно транслювати значення та смисли реципієнту, а й впливати на сприймання і розуміння ним повідомлення, змінюючи не лише когнітивні, а й емоційно-смислові структури його свідомості. Найбільш розповсюдженою формою передачі інформації через вербальний комунікаційний канал є текстова форма, яка дає змогу впорядковувати інформацію і вибудовувати повідомлення так, щоб досягти завдань, які ставив перед собою його автор, зокрема, завдань психологічного впливу на свідомість людини. 
Важливим чинником протидії негативним інформаційним впливам є медіаінформаційна грамотність населення. Дослідження Інституту соціальної та політичної психології НАПН України висвітлили проблему недостатньої медіакультури учнівської молоді, що набула актуальності в умовах інфодемії як інформаційної епідемії, яка поширюється у соціальних медіа і через фальшиві новини, дезінформацію, спекуляції щодо пандемії COVID-19. Також медіакультура молоді залишається актуальною проблемою в умовах потужного ідеологічного проросійського впливу, спрямованого на спотворення цінностей і смислів українського суспільства, руйнування національної ідентичності. В умовах інформаційної війни перешкодою ворожій пропаганді може стати розвиток медіаінформаційної грамотності молоді та її інформаційного патріотизму.

Впровадження компетентнісного підходу в освітні практики актуалізувало низку проблем, пов'язаних із інформаційним супроводом становлення компетентного громадянина. Суперечливість, розмитість, схематичність, міфологічність уявлень і практик спільноти про компетентного громадянина, які транслюються 3МІ та соціальними мережами, негативно позначається на розвитку громадянських компетентностей молоді.

Пандемія коронавірусу спричинила глобальний режим надзвичайної ситуації у світі, що значно похитнуло впевненість пересічної людини у власному майбутньому. В умовах невизначеності надзвичайно гостро постає потреба в особистостях, які спроможні належно відповісти на виклики мінливого сьогодення, здатні формувати системи внутрішньої детермінації життєдіяльності, що спонукає їх до самоосвіти та саморозвитку.

Пандемія COVID-19 стала серйозним випробуванням не лише для українського суспільства, а й для всього людства. Під час карантину спостерігалися зміни як на рівні психіки окремої особистості, так й на макросоціальному рівні. Карантинні умови значно вплинули й на організацію дистанційної та змішаної роботи провідних психологічних інституцій України.

Вчені Відділення психології, вікової фізіології та дефектології НАПН України активно включилися у діяльність, спрямовану на психологічну підтримку населення, надання психологічної допомоги в ситуаціях гострої кризи, пов'язаної, насамперед зі стресовими ситуаціями, викликаними як самою коронавірусною хворобою, так і змінами звичного способу життя, зокрема, самоізоляцією, втра- тою роботи, змінами в стосунках з оточуючими, проблемами в сім'ї тощо.

Основними напрямами діяльності для допомоги населенню у вирішенні зазначених проблем були такі.

Науково-інформаційний і консультативний, які відрізнилися запровадженням нової системи психологічної роботи з різними верствами населення, а саме організовано:

По-перше, волонтерський проєкт із психологічної підтримки населення під час карантину, в рамках якого здійснювалося дистанційне інформування та надання рекомендацій щодо опанування собою у стресових ситуаціях на карантині, оптимізації спілкування у сімейному колі під час самоізоляції, підвищення стресостійкості. Цей проєкт організовано Інститутом психології імені Г.С. Костюка НАПН України та громадською організацією «Небокрай».

По-друге, волонтерські проєкти підтримки лікарів і членів їхніх сімей.

По-третє, постійно працює «Телефон довіри» при Кризовому центрі медико-психологічної допомоги Інституту психології імені Г.С. Костюка НАПН України, у рамках якого проводиться систематичне онлайн-консультування різних категорії населення.

По-четверте, волонтерський проєкт разом із ТОВ «Східноєвропейський колегіум територіальної державної служби та місцевого самоврядування», у рамках якого реалізовувалася психологічна підтримка людей під час карантину.

На організаційній базі Навчально-практичного центру Інституту соціальної та політичної психології НАПН України разом із Інститутом психології ім. Г.С. Костюка НАПН України та факультетом психології Київського національного університету імені Тараса Шевченка проведено два цикли академічних онлайн-семінарів, присвячених резонансним суспільно значущим темам:

1) «Досвід карантину: дистанчійна психологічна допомога і підтримка» (23 квітня 2020 р.);

2) «Дистанційні психологічні дослідження в умовах пандемії COVID-19 і карантину» (15 травня 2020 р.), у яких взяли участь, відповідно, 610 і 200 фахівців з усіх областей України.

Наукові дослідження, проведені в цей період, показали, що пандемія COVID-19 проявила підвищену вразливість окремих професійних, гендерних і вікових груп населення.

Зокрема, за даними досліджень Інституту соціальної та політичної психології НАПН України 
в ситуації дискримінаційних ризиків опинилися педагогічні працівники. Це зумовлено асиметричним розподілом відповідальності за організацію навчального процесу і дотримання усіх карантинних норм, відсутністю єдиних стандартів організації навчального процесу в умовах пандемії, недостатнім технічним, фінансовим, методичним, психологічним забезпеченням дистанційного навчання, проблематичністю використання педагогічними працівниками засобів індивідуального захисту тощо.

В Інституті психології імені Г.С. Костюка НАПН України було здійснено:

- теоретико-методологічне обґрунтування засобів надання психологічної допомоги населенню, зокрема визначено поняття «коронавірусна тривога», перекладено та адаптовано до вітчизняних реалій методики допомоги медичному персоналу, який працює із хворими на COVID-19, обґрунтовано зв'язок психологічних реакцій людей на пандемію із попереднім досвідом подолання кризових життєвих ситуацій;

- проаналізовано практику використання системи MOODLE для дистанційного навчання студентів закладів вищої освіти та умови оволодіння ними загальними і спеціальними компетентностями;

- розроблено практичні рекомендації щодо нормалізації психоемоційного стану та підвищення стресостійкості людей, які опинилися у ситуації вимушеного карантину.

Виклики пандемії актуалізували необхідність осмислення перспективних напрямів в освіті. Досвід вчених Інституту психології імені Г.С. Костюка НАПН України показав, що сьогодні величезного значення набувають дослідження проблеми дистанційної освіти, зокрема розробка мережецентричного освітнього середовища, знаннєво орієнтованих технологій в освіті, технологій трансферу знань в освітньому процесі, методичних і технологічних основ наукової освіти для різних вікових груп, розробка психологічних практик і технологій розвитку особистості. Застосування інновацій у навчанні вже неможливо розглядати окремо від технологій проєктування віртуальних освітніх середовищ, створених за допомогою програмного забезпечення і комп'ютерних мереж.

На основі проведених досліджень, волонтерського та практичного досвіду науковцівпсихологів стала можливою розробка і застосування дієвих стратегій психологічної допомоги населенню для подолання наслідків самоізоляції, перенесеного захворювання, різних типів втрат за час пандемії. Тому перспективним видається удосконалення та впровадження технологій для збереження психологічного здоров'я та благополуччя громадян, поширення науково обґрунтованої, достовірної і корисної інформації, рекомендацій і методик із професійної допомоги та самодопомоги.

У дослідженнях Інституту спеціальної педагогіки і психології імені Миколи Ярмаченка НАПН України показано, що в умовах соціальної ізоляції, викликаної пандемією COVID-19, у родин дітей із особливими потребами виникають і наростають негативні психічні явища: депривація певного блоку основних особистісних потреб, негативні психоемоційні стани, почуття самотності й ін. Дослідження динаміки цих негативних явищ свідчить, що їх інтенсивність та відсоток родин, у яких вони діагностуються, зростають прямо пропорційно терміну перебування в умовах соціальної ізоляції. Це, своєю чергою, негативно впливає на соціальний розвиток дітей, гальмуючи успішність реабілітаційного процесу.

Чимало досліджень і практичних напрацювань присвячено інтегруванню дітей і молоді з особливими потребами до загальноосвітнього простору. Насамперед це особистісна орієнтація освіти, створення рівних можливостей для дітей та молоді у здобутті якісної освіти, забезпечення варіативності здобуття базової або повної загальної середньої освіти відповідно до здібностей та індивідуальних можливостей. Розроблено моделі дистанційного навчання таких осіб в умовах карантину, які дають змогу працювати вдома з усім класом під керівництвом учителя, який також може стати спікером для батьків у допомозі в оволодінні методами засвоєння навчальних знань.

Здійснюється і чимало заходів щодо підготовки фахівців до надання психологічної допомоги сім'ям, які виховують дітей з особливими потребами:

- проводяться спеціальні семінари і групи супервізійного супроводу для психологів, соціальних педагогів і представників інших суміжних професій;

- розробляються і розповсюджуються (переважно через соціальні мережі) методичні матеріали інформативного і просвітницького характеру тощо.

Було з'ясовано, що критичний період в адаптації родин дітей із особливими потребами до 
соціальної ізоляції розпочинається із другого місяця. Відповідно у цей період показники за шкалами відчуженості, а згодом і конфліктності, агресивності та ригідності у міжособистісній взаємодії батьків і дітей долають поріг середніх показників у бік високих значень. Тобто можна говорити про дисбаланс, який виникає у цей період між інтенсивністю впливу стресогенного чинника (соціальної ізоляції) та адаптивними можливостями батьків і поглиблюється зі збільшенням тривалості перебування родин у цих умовах. Також було виявлено чинники, які зумовлюють успішність адаптації родин в умовах соціальної групової ізоляції: активність, соціальнопсихологічна позиція та адекватність прийняття соціальної ролі.

Наведені факти змушують говорити про те, що питання, пов'язані 3 наданням дистанційної психологічної допомоги родинам дітей із особливими потребами у кризових ситуаціях, які знаходяться в умовах ізоляції, не можуть надалі залишатися у межах надання поодинокої допомоги батькам чи дітям, а має бути розроблена дистанційна система психологічного супроводу для усієї родини.

Події, пов'язані з воєнною агресією Росії та проведенням нею гібридної війни, актуалізували у громадян України потребу осмислити зміни усталеного способу життя, застосувати найбільш придатні способи психологічного захисту, виробити засоби протидії індивідуальній і колективній травмі та ефективні стратегії зараджувальної поведінки.

Аналіз соціальної ситуації дає змогу визначити кілька тенденцій у розвитку негативних психологічних наслідків воєнних дій на сході України:

- зростає маргіналізація суспільства за рахунок розмивання загальноукраїнської ідентичності;

- відчутно утруднюється побудова програм перспективного майбутнього;

- посилюється взаємозв' язок негативних наслідків війни із криміналізацію побутових конфліктів;

- підвищується сенситивність громадян до маніпулятивних впливів (зокрема через засоби масової комунікації) з боку агресора;

- зростає кількість маніпуляцій з боку агентів внутрішньої політики для досягнення парціальних політичних цілей;

- консолідуються настрої, які перешкоджають інтеграційним процесам у суспільстві;

- посилюється комбінований вплив різних внутрішніх і зовнішніх соціальних, політичних, економічних та інших факторів на виникнення і поширення негативних психологічних явищ, пов'язаних із війною.

Дослідження психологічних стратегій адаптації спільноти до умов і наслідків воєнного конфлікту, виконані в Інституті соціальної та політичної психології НАПН України, показують, що набутий українцями травматичний досвід спричиняє не лише негативні наслідки, а й може посилювати відновлювальні зусилля, зокрема щодо пошуку нових цілей і нового сенсу життя, змінювати ставлення людини до себе, до інших і до світу. Наразі в українському суспільстві відбувається хоча й невпевнений, та все-таки простежуваний перехід від застосування консервативнорутинних стратегій адаптації до вироблення проактивно-трансформаційних психологічних стратегій як найбільш ефективного варіанта індивідуальної і колективної зараджувальної поведінки в різних сферах життєдіяльності. При цьому основним соціально-психологічним чинником напруження в українському суспільстві залишається істотна політична поляризація найбільше у вигляді протистояння проукраїнської більшості і проросійської меншості. Інтенсивні публічні дискусії між представниками цих двох груп, з одного боку, сприяють взаємному з'ясуванню поглядів та узгодженню позицій, але 3 іншого - загострюють громадсько-політичні суперечності та розхитують ментальне поле, роблячи його вразливим до зовнішніх антиукраїнських впливів.

Убезпечення вразливих верств населення в умовах гібридної війни потребує розроблення психологічних засобів (лекції-бесіди, групова дискусія, фокус-групи, соціально-психологічний тренінг), застосування яких показало свою ефективність, про що свідчать результати групової роботи з представниками територіальних спільнот, педагогічної спільноти, внутрішньо переміщеними особами, родинами учасників АТО щодо усвідомлення ними можливостей активізації колективних зусиль, спрямованих на подолання наслідків воєнного конфлікту та підвищення адаптивності в умовах новітніх суспільних викликів.

Вченими Інституту психології імені Г.С. Костюка НАПН України створено інноваційну психодинамічну модель психотравми, побудовану з акцентом на феномені структурної регресії як важливому факторі розуміння механізмів патогенезу у ветеранів бойових дій. Розроблено комплекс авторських діагностичних методик, спря- 
мованих на виявлення характеристик структурної регресії у ветеранів відповідно до моделі психотравми та алгоритму їх співставлення з реальною сукупністю і особливостями ознак посттравматичного стресового розладу в конкретної особи.

Побудовано психотерапевтичну технологію із визначенням стратегії і принципів стабілізації процесу регресії у перспективі досягнення структурного відновлення особистості; виявлено можливості гнучкого формування тактичних напрямів роботи з ветеранами, виділенням першорядних мішеней психотерапевтичного впливу, відповідних психотерапевтичних засобів і послідовності інтервенцій для конкретних осіб.

Розроблено «Карту психологічного супроводу ветерана» як внутрішній протокол для роботи 3 ветеранами в умовах стаціонару.

Запропоновано теоретико-методологічну модель особистісного профілю дітей військовослужбовців із симптомами посттравматичного стресового розладу, які визначаються як специфічна група ризику: здійснено типізацію психологосоціальних стрес-чинників, показано феномен циркулювання симптомів посттавматичного стресового розладу у дітей та визначальну роль психоемоційного стану батьків у їх виникненні, перебігу та розвитку.

Побудовано психотехнологію допомоги дітям військовослужбовців із проявами посттравматичного стресового розладу, в основу якої покладено ідею розвитку життєстійкості дітей через відновлення сприятливого психоемоційного контакту в родині, що враховує три компоненти: роботу із соціальним середовищем, в якому перебувають діти, роботу з близьким оточенням дитини, роботу із самою дитиною.

Розроблено психотехнологію розвитку резільєнтності психологів/психотерапевтів, які працюють із постраждалими, на основі інтегративного підходу, що включає психодинамічні, когнітивноповедінкові, екзистенційні та інші методи та техніки, котрі забезпечують ресурсну підтримку фахівців, трансформацію їх глибинного досвіду та відновлення цілісності особистості, опанування ефективними копінг-стратегіями долання стресу та асертивною поведінкою.

Згідно з Національною стратегією розбудови безпечного і здорового освітнього середовища у Новій українській школі, схваленою Указом Президента України від 25 травня 2020 р. № 195/2020, визначено завдання, які потребують належного соціально-психологічного забезпечення та супроводу. Підвідомчі установи Відділення психології, вікової фізіології та дефектології НАПН України наразі реалізують кілька експериментів всеукраїнського рівня, спрямованих на розв'язання нагальних питань, що пов'язані з забезпеченням психологічної безпеки особистості та спільноти в освітній сфері.

Зокрема, під час експерименту «Розробка системи підвищення психологічної готовності учасників освітнього процесу до дій у разі загрози, виникнення і подолання наслідків надзвичайної ситуації» Інститут соціальної та політичної психології НАПН України відпрацьовує такі інновації:

1) формування спільно з Державною службою України $з$ надзвичайних ситуацій (ДСНС) «дорожньої карти» взаємодії між ДСНС і працівниками психологічних служб системи освіти та іншими державними та недержавними установами у разі виникнення надзвичайної ситуації;

2) розроблення методичних рекомендацій для працівників психологічних служб системи освіти, зокрема, практичних психологів закладів освіти як координаторів із забезпечення психологічної безпеки учасників освітнього процесу (учні, батьки, педагогічний колектив);

3) розвиток у практичних психологів закладів освіти та педагогічного колективу навичок надання першої психологічної допомоги потерпілим від травматичних подій;

4) створення базової батареї методик експресдіагностики психоемоційного стану та психологічної опірності особистості; проведення інтерактивних занять із фахівцями з питань оволодіння цим діагностичним інструментарієм;

5) підготовка працівників психологічних служб системи освіти до ефективного реагування (дій) у надзвичайних ситуаціях і до профілактики (превенції) негативних психологічних наслідків переживання особистістю травматичних подій (інформаційна та діагностична робота в освітянському середовищі та громаді, виявлення груп ризику, поственція суїцидів та суїцидальних спроб).

Мінімізація негативних психологічних проявів, пов'язаних із військовим конфліктом на сході України, передбачає вирішення наступних завдань:

- розроблення та реалізація психологічних програм супроводу реінтеграційних процесів для громадян, які нині перебувають на окупованих територіях, біля лінії розмежування; 
- розроблення та реалізація комплексів заходів, орієнтованих на зниження рівня мілітаризації суспільної свідомості;

- розроблення заходів, спрямованих на збереження і розвиток загальнонаціональних цінностей та ідентичності, зниження рівня політичних, соціальних, національних і конфесійних суперечностей, що можуть призвести до посилення конфліктної ситуації.

Група проблем, пов'язана з психологічною безпекою особистості та спільноти, загалом потребує невідкладного вирішення. Зокрема, йдеться про необхідність:

1) формування і розвитку безпечного комунікативного простору та розроблення відповідних психологічних засобів запобігання інформаційним загрозам в освітньому середовищі та сфері соціальних інтеракцій загалом. Нові інформаційні небезпеки, серед яких є доступ і безпосереднє залучення до небажаного контенту - такого, як порнографія, жорстокість, наркотики, міжнаціональна та релігійна ворожнеча, расизм, екстремізм, молодіжні агресивні течії тощо, а також ведення гібридної війни проти України, зробили нагальними пошук ефективних стратегії запобігання негативним психологічним явищам у політико-правовій сфері в умовах воєнного конфлікту;

2) створення та апробація відповідних технологій психологічної підтримки освітніх реформ. Психологічні впливи, поєднані із виховними, повинні зосереджуватися на формуванні у підростаючого покоління культури безпеки, відповідальності за здійснені дії в інформаційному просторі, виховання й укріплення духовноморальних цінностей, патріотизму;

3) розроблення стратегій психологічного супроводу різних верств населення в умовах надзвичайних ситуацій;

4) підготовки відповідних програм психологічного супроводу вразливих верств населення в умовах гібридної війни.

Особливістю сприйняття людиною реальності $\epsilon$ те, що воно завжди обмежене біологією. Тому людина сприймає світ, себе та інших людей такими, якими зробили ії відчуття. Людська свідомість довіряє усьому, що отримує через чуттєвий досвід і знає світ лише таким, яким його трактує наш розум з усіма його когнітивними спотвореннями. Тому людина не відчуває реального світу таким, яким він $€$ насправді. Це призводить до того, що у кожної особистості створюється своя унікальна модель світу, яку збагнути дуже складно, а проникнути у духовний світ людини неможливо. Проте так можна було висловлюватися кілька десятків років тому. Зараз людство стоїть перед революційним гігантським поступом у вивченні особистості за допомогою сучасних нейротехнологій, які власне дають нам змогу побачити світ очима іншої людини та дізнатися, що вона відчуває.

Інститут психології імені Г.С. Костюка НАПН України не стояв осторонь цих нових тенденцій і в лабораторії психології навчання у 2016 р. впроваджено інноваційні нейротехнології. Також в Інституті за цим напрямом опубліковано першу монографію «Нейропсихологія девіантної поведінки», у якій показано, як саме ці технології використовувати у діагностиці та психокорекції. Отже, ці методи дають змогу об'єктивно інтерпретувати результати психологічного дослідження, вибудовувати теоретичні конструкти не на припущеннях, як це робили психологи до нас, а на основі фактів. Практично в Інституті психології імені Г.С. Костюка НАПН України відкрито нову сторінку в історії вітчизняної психології, коли вона перестає бути мистецтвом тлумачення і припущень, а стає наукою, у якій елемент суб'єктивності дослідника вилучено. Нейроінтерфейси - це пристрої, які належать до технології інтерфейс: мозок-комп'ютер (BCl - Brain Computer Interface). Крім того, у фаховій літературі цю технологію ще називають інтерфейс розуммашина (MMI - Mind Machine Interface), прямий нейронний інтерфейс (DNI - Direct Neural Interface) та інтерфейс мозок-машина (BMI Brain Machine Interface). Ця нейротехнологія спрямована на оцінку когнітивних показників, моніторингу емоцій, розпізнання лицевої експресії, рухів голови, а також управління віртуальними чи фрізичними об' єктами.

Дуже важливим напрямом діяльності Інституту було розроблення методів нейропсихокорекції посттравматичних стресових розладів (ПТСР) у воїнів, які повернулися з війни. Ці методи $\epsilon$ надзвичайно ефективними і дають змогу виліковувати найтяжчі розлади. За створені методи НАПН України нагородила грамотами працівників Інституту. Відмінністю від класичних методів психотерапії $€$ те, що запропонована нейропсихокорекція відбувається не «на сліпу», а під постійним нейромоніторингом, що дає змогу одразу змінювати її тактику і робити прогнози на майбутнє. 
Завдяки окулографії ми знаємо, куди дивиться досліджуваний, а опираючись на заміри основних когніцій та емоцій, точно знаємо, що цікаво, що важко дається, а що є незрозумілим для учнів і студентів. «Нова школа» власне й потребує такого навчального матеріалу. Ми маємо всі засоби і ресурси для реалізації цього проєкту.

Нейротехнології дають нам змогу напряму закомунікувати мозок із комп'ютером і думкою, тобто ментальними командами управляти або у віртуальному середовищі, або механізмами, наприклад дроном, автомобілем, протезами, штучним тілом тощо. Завдяки цьому, вчені Інституту вже створили біологічне безсмертя і можуть продовжити своє буття або у віртуальному світі, або реальному.

Більше того, на сучасному етапі розвитку науки ці нейронні мережі можна побачити під мікроскопом неінвазивно. Суть методу полягає у тому, що завдяки вірусу вбудовується ген фрлуоресцениії водоростей до регуляторного гену нейронів, пов'язаних із «конкретною інформацією», і під час освітлення мозку надмірно збуджується винятково ця мережа нейронів і з'являється відповідна реакція організму. Важливою $€$ можливість перевірити, чи справді збудження ансамблю клітин приводить до появи «цієї реакції». Onтогенетика дає змогу сказати, які саме конкретно клітини нервової системи причетні до конкретної функції, реакції чи психічного розладу.

Заслуговують на увагу результати моніторингу нейроінтерфейсом когнітивно-емоційних реакцій молоді нормотипової та з девіантною поведінкою до та під час пандемії COVID-19.

Постійні трансформаційні процеси у суспільстві та серйозні виклики сьогодення (такі, як діджиталізація, роботизація, збройні конфлікти, економічний спад, пандемія COVID-19, екологічні проблеми) змушують людину постійно адаптовуватися до нових реалій. Проте інтенсивність і динаміка цих змін спричиняє психологічну дезадаптацію у молоді, яка проявляється девіаціями у поведінці: високою агресією, нетерпимістю один до одного, адикціями, суїцидальною поведінкою та сексуальними девіаціями. Загалом масштаби девіантної поведінки чинять загрозу національній безпеці багатьох країн. Тому зараз, як ніколи, необхідно здійснювати пошук ефективних рішень для подолання психологічних наслідків пандемії COVID-19 і підготуватися до подібних ситуацій. Проте для цього необхідно знати, як змінюються когнітивно-емоційні реакції молоді на психологічні події до карантину та під час. Саме ці дані лонгітюдного дослідження дадуть змогу вибудовувати адекватні програми для профілактики девіацій серед молоді, спричинених перебуванням в умовах природних і техногенних надзвичайних ситуацій.

Теоретична цінність дослідження полягає у впровадженні передових наукоємних нейротехнологій під час вивчення девіантної поведінки у молоді, спричиненої пандемією COVID-19. Адже психологічні теорії девіацій, які спираються на класичну психологію, сповнені сцієнтизмом (методологічною обмеженістю пізнання феномена), універсалізмом (пошуком універсального закону розвитку розладу), індивідуалізмом (інтереси індивіда є пріоритетними над інституціональними інтересами), механістичним розумінням казуальності (дуалістичний поділ причин, які зароджуються у внутрішньому світі чи зовнішньому). Варто відзначити, що у цих теоріях людину часто розглядають «як таку» - усереднено, без гендерних особливостей, не враховують інстинкти виживання, емоційну, когнітивну сфери, не беруть до уваги нейропсихологічні особливості, а саме - порушення нейропсихологічних факторів. Сьогодні відомо, що у кожної особистості мозок неповторний, а іноді відмінність між людьми становить 40 разів за деякими цитоархітектонічними полями. Зрештою мозок сучасної людини не схожий на мозок людей, які жили півстоліття тому. Варто додати, що новий коронавірус SARSCoV-2 вражає не тільки дихальну систему і ослабленні місця в організмі, де були хронічні процеси, а спричиняє серйозне ураження серця, судин, нирок, шкіри, а також нервової системи. Вважаємо за доцільне нагадати, що $є$ чотири шляхи патогенетичного впливу SARS-CoV-2 на ЦНС: 1. Вірус потрапляє безпосередньо в мозок і спричиняє енцефаліт. 2. Мозок уражається від автоімунного процесу, який спровокований вірусом. З. Мозок страждає від низького рівня кисню у крові. 4. Мозок ушкоджується внаслідок згортання крові.

У дослідженні застосовано сучасні біометричні технологій для комплексного вивчення девіантної поведінки молоді - $\mathrm{BCl}$ (Brain Computer Interface), що дають змогу отримати нові наукові результати, позбавленні суб'єтивізму дослідників. Адже ці технології дозволяють знімати 3 мозку 128 раз на секунду показники про підсвідомі реакції на аудіовізуальні подразники. 
Дослідження електричної активності мозку у лабораторних умовах є важливими. Проте людина живе не в лабораторії з давачами на голові і не закомунікована дротами до реєстраційного пристрою, а у звичних умовах, взаємодіє з навколишнім світом та іншими людьми. На наше переконання, одномоментні заміри електричної активності мозку в лабораторіях не достатньо відображають динаміку й особливості особистості. Проте якщо подразник чи психодіагностична методика $€$ стандартизованими, то можливо порівняти дані між групами.

Поява нейроінтерфейсу ще ніколи не робила настільки простим під'єднання мозку до комп'ютера і відкриває для психологів принципово нові можливості вивчення поведінки людини. Тепер відбувається активна побудова нової доктрини в нейронауках, до якої ми маємо причетність. Це дало змогу психологам точно знати, а не припускати, які зараз у досліджуваного когнітивноемоційні показники.

Для вивчення основних когнітивних та емоційних показників було використано мобільний 14канальний нейроінтерфейс EMOTIV Epoc+. Також було використано програмне забезпечення для моніторингу ЕЕГ та візуалізації електричної активності мозку, а також для отримання трансформованих ЕЕГ-патернів у вигляді основних когнітивно-емоційних показників: MуEMOTIV, EMOTIV Map Brain Activity Map та EmotivPRO.

Згідно з дослідженням можна зробити висновки, що молодь максимально може витримати три місяці жорстких обмежень. Оскільки у наступні місяці ні правові санкції, ні страхітлива пропаганда вже не спрацьовує. У період короткочасної аномії, яка спричинена перебудовою у суспільстві внаслідок пандемії, дуже комфортно почуває себе молодь із девіаціями. Натомість нормотипова сприймає нову реальність стресово.

\section{СПИСОК ВИКОРИСТАНИХ ДЖЕРЕЛ}

Інститут психології імені Г.С. Костюка НАПН України. (2017). Актуальні проблеми психології : збірник наукових праць, VII(44). https://lib.iitta.gov.ua/710105/ Інститут психології імені Г.С. Костюка НАПН України. (2020). Усамітнення та самотність в житті особистості : збірник тез за матеріалами круглого столу (on-line, 24 квітня 2020 р.). Київ: ДП «lнформаційно-аналітичне агентство». https:// lib.iitta.gov.ua/720390/

Інститут психології імені Г.С. Костюка НАПН України. (2020). Освітній простір в контексті гуманістичної парадигми: психологічні пріоритети сучасносmi : збірник наукових праць (С.Д. Максименко, ред.). Ottawa, Canada: Accent Graphics Communications \& Publishing. https://lib.iitta.gov.ua/720332/
Інститут психології імені Г.С. Костюка НАПН України (2020). Психологічні виміри особистісної взаємодії суб'єктів освітнього простору в контексті гуманістичної парадигми : збірник тез наукових доповідей III Всеукраїнської конференції з міжнародною участю (Київ, 31 березня 2020 р.) (С.Д. Максименко, ред.). Київ: Інститут психології імені Г.С. Костюка НАПН України. https:// lib.iitta.gov.ua/720724/

Інститут психології імені Г.С. Костюка НАПН України. (2020). Сучасні психологічні вимоги до підручника для Нової української школи : збірник тез наукових доповідей круглого столу, присвяченого 75-річчю створення Інституту психології імені Г.С. Костюка НАПН України (Київ, 24 листопада 2020 р.) (С.Д. Максименко, ред.). Київ: Інститут психології імені Г.С. Костюка НАПН України. https:// lib.iitta.gov.ua/722535/

Литвинчук, Л.М. (2016). Проблема анозогнозії наркологічних хворих як фактор виявлення закономірностей процесів реабілітації та ресоціалізації. Актуальні проблеми психології, 14(11), 38-49. https:// lib.iitta.gov.ua/708978/

Максименко, С., Максименко, К., \& Ірхін, Ю. (2020). Системність психіки людини і психології навчання. Проблеми сучасної психології, (50), 146-166. https://doi.org/10.32626/2227-6246.2020-50.146-166

Максименко, С., Ткач, Б., Литвинчук, Л., \& Онуфрієва, Л. (2019). Нейропсихолінгвістичне дослідження політичних гасел із зовнішньої реклами. Psycholinguistics, 26(1), 246-264. https:// doi.org/10.31470/2309-1797-2019-26-1-246-264

Максименко, С.Д. (2017). Генетична психологія учіння людини : монографія. Київ: Видавничий Дім «Слово». https://lib.iitta.gov.ua/709727/

Максименко, С.Д., \& Губенко, О.В. (2018). Досвід реалізації генетико-моделюючого методу в дослідженні психологічних механізмів наукового відкриття (на прикладі історії створення теорії відносності). Актуальні проблеми психології, 14(1), 199-209. https://lib.iitta.gov.ua/714315/

Максименко, С.Д., \& Кокун, О.М. (2019). Принципи розробки сайтів для професійної психодіагностики в різних спеціальностях. Інформаційні технології $i$ засоби навчання, 73(5), 284-292. https:// doi.org/10.33407/itlt.v73i5.2963

Максименко, С.Д., \& Лысенко, А.С. (2020). Проблема виртуальной зависимости у подростков. Психиатрия, психотерапия и клиническая психология, 11(2), 256-267. https://bit.ly/3doQHGF

Максименко, С.Д., Карамушка, Л.М., Креденцер, О.В., Бендерець, Н.М., \& Шевченко, А.М. (2020). Психологічне здоров'я персоналу організацій: проблеми та технології забезпечення. Вісник Начіональної академії педагогічних наук України, 2(1). https:// doi.org/10.37472/2707-305X-2020-2-1-7-10

Максименко, С.Д., Кокун, О.М., \& Тополов, Є.В. (2011). Адаптація психодіагностичних методик: шкала досвіду агресивних впливів, шкала професійної автономності та шкала професійної мобільності. Практична психологія та сочіальна робота, (3), 25-31. https://lib.iitta.gov.ua/1662/

Максименко, С.Д., Костюк, О.В., Максименко, К.С., Немеш, О.М., \& Луньов, В.Є. (2020), Мультилінгвіс- 
тичний дискурс невротизачій майбутніх лікарів : монографія (С.Д. Максименко, ред.). Київ: Видавництво Людмила.

Максименко, С.Д., Максименко, К.С., Литвинчук, Л.М., \& Немеш, О.М. (2020). Тенденції та динаміка мотиву діяльності медичного персоналу середньої ланки на різних етапах професійного становлення. Психологічне здоров'я, (2). https:// doi.org/10.32689/2663-0672-2020-2-5-40-60

Максименко, С.Д., Руденко, Я.В., Кушнєрьова, А.М., \& Невмержицький, В.М. (2021). Психічне здоров'я особистості : навчальний посібник. Київ: Видавництво Людмила.

Максименко, С.Д., Чепелєва, Н.В., Смульсон, М.Л. \& Гуменюк, Г.В. (ред.). (2016). Особистість в умовах кризових викликів сучасності : матеріали методологічного семінару НАПН України (24 березня 2016 р.). Київ: НАПН України. https:// lib.iitta.gov.ua/704987/

Національна академія педагогічних наук України. (2021, 9 квітня). Відбувся методологічний семінар "Актуальні проблеми психологічної протидіі негативним інформаційним впливам на особисmiсть в умовах сучасних викликів». http:// naps.gov.ua/ua/press/releases/2275/

Національна академія педагогічних наук України. (2021, 9 квітня). Про психологічну протидію негативним інформаційним впливам на особистість в умовах сучасних викликів йшлося 8 квітня на Методологічному семінарі НАПН України. Facebook. https://www.facebook.com/ua.naps/ posts/4136182026427200

Павлюк, М.М., \& Шепельова, М.В. (2020). Сучасні психологічні технології надання психологічної допомоги сім'ям постраждалих у подоланні складних життєвих обставин : практичний посібник. Київ: Інститут психології імені Г.С. Костюка НАПН України. https:// lib.iitta.gov.ua/723398/

Слюсаревський, М.М., Найдьонова, Л.А., \& Вознесенська, О.Л. (ред.). (2020). Досвід переживання пандемії covid-19: дистанційні психологічні дослідження, дистаниійна психологічна підтримкa : матеріали онлайн-семінарів 23 квітня 2020 р. «Досвід карантину: дистанційна психологічна допомога і підтримка» та 15 травня 2020 р. «Дистанційні психологічні дослідження в умовах пандеміï covid-19 і карантину». https:// lib.iitta.gov.ua/721663/

Maksymenko, S. (2015). Genesis of Personality Existence : monograph. Montreal: Accent Graphics Communications.

Maksymenko, S. (2020). Genetic psychology: problems and perspective (basics of concept). Fundamental and Applied Researches in Practice of Leading Scientific Schools, 40(4), 27-33. https://farplss.org/index.php/ journal/article/view/720

Maksymenko, S., Kokun, O., Korobeynikov, G., Cynarski, W.J., Korobeinikova, L., Serdiuk, L., Adyrkhaiev, S., Adyrkhaieva, L., Nikonorov, D., \& Smoliar, I. (2021). Features of the components of students' psychophysiological readiness to work as teachers. Ido Movement for Culture. Journal of Martial Arts Anthropology, 21(2), 11-18. https://doi.org/10.14589/ido.21.2.3

Maksymenko, S., Nemesh, O., Maksymenko, K., \& Nabochuk, A. (2020). Psychological Peculiarities of Understanding by Students Internet Texts. Psycholinguistics, 28(1), 187-213. https:// doi.org/10.31470/2309-1797-2020-28-1-187-213

\section{ACTUAL PROBLEMS OF PSYCHOLOGICAL RESISTANCE TO HARMFUL INFORMATION IMPACT ON PERSONALITY AND WAYS TO OVERCOME THEM \\ Scientific report at the methodological seminar of the National Academy of Educational Sciences of Ukraine "Actual Problems of Psychological Resistance to Harmful Information Impact on Personality under Current Challenges" (April 8, 2021)}

Serhii Maksymenko

DSc in Psychology, Professor, Full Member (Academician) of NAES of Ukraine, Academician Secretary of the Division of Psychology, Age Physiology and Defectology, National Academy of Educational Sciences of Ukraine, Kyiv, Ukraine; Director, G.S. Kostiuk Institute of Psychology of the National Academy of Educational Sciences of Ukraine, Kyiv, Ukraine

Abstract. In itself, the essence of the social situation that has occurred in the world is that the importance of the psychological factor of personal existence in the formation and functioning of the process caused by the pandemic. We do not undertake to analyze these components as such, but we can only state some things that can be considered from a psychological point of view, which capture all segments of the population, all key state, political, economic positions from the point of view of different people, different segments of the population, in different statuses - the same things. It is a certain mania of persecution and observance of certain rules of protection, which has become a manic state in society. The mania of persecution becomes the dominant unit. The second point is the illogicality of thinking, which is manifested in an inadequate attitude to the world as a whole, and to themselves, to relatives, friends.... And this is a specific form of bifurcation of consciousness. When there are rather incomprehensible paradoxical aggressive and depressive syndromes. On the one hand, it is aggression, and on the other hand, it is the fear of everyone around.

Keywords: resistance to harmful information impact; personality; neuroses; COVID-19; reflex. 